The Sense of Humor 



\title{
The Sense of Humor
}

Explorations of a Personality Characteristic

\author{
Edited by
}

Willibald Ruch

Mouton de Gruyter

Berlin - New York 
Mouton de Gruyter (formerly Mouton, The Hague)

is a Division of Walter de Gruyter GmbH \& Co. KG, Berlin.

The hardcover edition was published in 1998 as volume 3 of the series Humor Research.

Printed on acid-free paper which falls within the guidelines of the ANSI to ensure permanence and durability.

The Library of Congress has cataloged the hardcover edition as follows:

The sense of humor : explorations of a personality characteristic / edited by Willibald Ruch.

$$
\text { p. cm. - (Humor research : 3) }
$$

Includes bibliographical references and indexes.

ISBN 3-11-016207-5 (alk. paper)

1. Wit and humor. - Psychological aspects 2. Personality.

I. Ruch, W. (Willibald) II. Series

BF575.L3S39 1998

$155.2^{\prime} 32-\mathrm{dc} 21$

98-15494

CIP

Die Deutsche Bibliothek - Cataloging-in-Publication Data

The sense of humor : explorations of a personality characteristic / edited by Willibald Ruch. - Berlin ; New York : Mouton de Gruyter, 1998

ISBN 3-11-016207-5

ISBN 978-3-11-019829-4

(C) Copyright 1998, 2007 by Walter de Gruyter GmbH \& Co. KG, D-10785 Berlin

All rights reserved, including those of translation into foreign languages. No part of this book may be reproduced or transmitted in any form or by any means, electronic or mechanical, including photocopy, recording or any information storage and retrieval system, without permission in writing from the publisher.

Cover design: Martin Zech, Bremen.

Printed in Germany. 